\title{
Exposure of children to aerosol during PE lessons
}

Jiří Šafránek, Ivana Turčová, Martin Braniš, Michal Hájek

Envigogika 12 (2) - Recenzované články/ Reviewed articles

Publikováno / Published 18. 12. 2017

DOI: $\underline{10.14712 / 18023061.554}$

\begin{abstract}
In periods of physical exercise, the greater the physical exertion, the greater the amount of air, including pollutants, which is inhaled, compared to sedentary activities. The school gym environment is in many aspects predisposed to high amounts of aerosol (particulate matter - PM) concentrations, which is cumulated in gym halls and re-suspended by exercising pupils during physical education (PE) lessons. PM concentrations (mainly its coarse particles) rise sharply according to the number of people exercising and the type of activity. The aim of our study was to estimate the aerosol exposure for 32 children exercising with increased ventilation in Prague primary school gyms (18 girls - 10 to 14 years and 14 boys - 10 to 13 years).
\end{abstract}

The indirect method of transferring heart rate (HR) to minute ventilation (VE) through the exponential regression curve was used to measure pulmonary ventilation. HR was measured by sport-testers during PE lessons. Results of rest and ventilation load values were compared with the values of aerosol weight concentrations, measured continually by a photometer Dust Track and by the Personal Cascade Impactor Sampler.

Results have shown that the average VE multiple during exercising reached 3.8 times in the observed group. The average HR of respondents in the measured exercise unit was 150.6 beats $\cdot \mathrm{min}^{-1}$ and the estimated $x$ VE 24.4 litres $\cdot \mathrm{min}^{-1}$. VE multiple values of individual pupils in an exercise unit correlate significantly $(r=0.78)$ with average HR values in the time unit. Aerosol concentrations reached in measured PE lessons from $\mathrm{PM}_{2.5} 22.4$ to 24.4 [ $\left.\mu \mathrm{g} \cdot \mathrm{m}^{-3}\right]$ and from $\mathrm{PM}_{10} 60.14$ to $101.12\left[\mu \mathrm{g} \cdot \mathrm{m}^{-3}\right]$. If the tested pupils raised their ventilation to the estimated 3.8 times their resting value, exposure to PM exceeded the sanitary limits set by WHO guidelines for school environments. Out of 112 observed days, in three Prague primary schools, $89 \%$ of days in school gyms and $46 \%$ of days outdoors were over this limit (under the above stated conditions of VE multiple).

The study results indicate that during increased physical load inhalation exposure exceeds pollutant limit concentrations. We recommend that indoor areas, in which pupils exercise, should be cleaned with more care than places in which pupils are sedentary.

\section{Keywords}

Pulmonary ventilation, particulate matter, school physical education. 


\section{Abstrakt}

Při zvýšené fyzické zátěži člověk nadýchá větší množství vzduchu včetně škodlivin a jiným způsobem než v klidovém režimu. Prostředí tělocvičen je v mnoha ohledech náchylné k vysokým koncentracím aerosolu (PM), který se v nich kumuluje a během tělesné výchovy (TV) se pohybem a činností cvičících resuspenduje. Koncentrace PM (především jeho hrubé frakce) se tak podle množství cvičenců a charakteru činnosti při cvičení výrazně zvyšují. Cílem naší studie bylo odhadnout expozici aerosolu za podmínek zvýšené ventilace u 32 cvičících dětí (18 dívek - 10 až 14 let a 14 chlapců - 10 až 13 let) na pražských základních školách.

Ke zjištění plicní ventilace jsme použili nepřímou metodu přepočtu srdeční frekvence (SF) na minutovou plicní ventilaci (VE) pomocí exponenciální regresní křivky. Provedli jsme laboratorní zátěžové vyšetření vybrané skupiny žáků a měření SF pomocí sport-testerů v průběhu hodiny TV. Výsledky klidových a zátěžových hodnot ventilace jsme porovnávali s hodnotami hmotnostních koncentrací aerosolu, které jsme v tělocvičně měřili kontinuálně fotometrem DustTrak a nízkoobjemovým kaskádovým impaktorem.

Výsledky ukázaly, že průměrný násobek plicní ventilace během cvičební jednotky dosáhl u sledované skupiny 3,8 násobku, oproti klidovým hodnotám. Průměrná SF respondentů za měřenou cvičební dobu byla 150,6 tepů· $\mathrm{min}^{-1}$. a vypočtená $\bar{x}$ VE 24,4 I·min ${ }^{-1}$. Hodnoty násobku ventilace jednotlivých cvičenců za cvičební jednotku významně korelují $(r=0,78)$ $s$ průměrnými hodnotami SF za stejnou dobu. Koncentrace aerosolu dosahovaly $v$ měřených

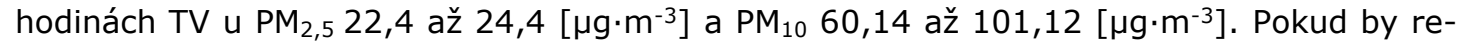
spondenti zvýšili ventilaci na vypočtený 3,8 násobek klidové hodnoty, jejich expozice PM by přesahovala limity hygienických požadavků pro školní prostředí dané dokumenty WHO. Ze 112 sledovaných dnů na třech pražských základních školách za výše uvedených podmínek násobku plicní ventilace bylo nadlimitních 89 \% dnů v tělocvičnách a 46 \% dnů venku.

Při zvýšené fyzické zátěži mohou odpovídat inhalační expozice stavům s nadlimitními koncentracemi škodlivin. V souvislosti s uvedenými poznatky lze doporučit, aby čistotě školního prostředí, kde dochází k vyšší fyzické zátěži, byla věnována větší péče, než místům, kde jsou žáci relativně v klidu.

\section{Klíčová slova}

Plicní ventilace; PM; školní tělesná výchova. 


\section{Introduction}

Children are very sensitive to polluted air. Therefore it is necessary to examine the quality of air in schools where children spend the major part of their day (Kotlík et al, 2001). Aerosol pollution in school gyms has been observed in several previous studies (Braniš, Šafránek, \& Hytychová, 2009, 2011; Braniš, \& Šafránek, 2011), and was found to exceed acceptable limit values. The assumption that concentration limits for indoor school environments are exceeded in school gyms makes it necessary to examine the overall exposure of children during higher pulmonary ventilation (VE). We presume that the exposure to aerosol in school gym environments during PE lessons can be unpleasant for children and during high level of exposure unhealthy for sensitive children (Daigle et al, 2003).

PE lessons in schools are often undertaken in indoor environments under various conditions. Essential factors influencing the quality of air in school gyms are: the age of the building, location of the gym in the school complex, location of the school in the local environment, local emissions, gym utilization, gym cleaning procedures, materials used during construction, gym equipment, and ventilation or air conditioning. It is also necessary to consider parallel conditions in outdoor environments and review the most suitable location for conducting PE lessons (Carlisle, \& Sharp, 2001).

Fairclough and Stratton (2005) found out that involvement in PE lessons declines from the $7^{\text {th }}$ grade, mainly among girls. In the case of a polluted gym with bad air quality, those who do not exercise may inadvertently be doing the right thing. This, however, contradicts the sense of having PE in the school curriculum. Considering the goal of PE, pupils should reach a certain level of physical load, which can be expressed by the average heart rate (HR). Stratton (1996) stated in his study of English children aged 9 to 15 that PE lessons can be considered efficient when HR reaches the average value of 150 beats a minute. The important factor of effective use of time during a PE lesson was also studied by Fairclough and Stratton (2005), Wang, Pereira, and Mota, (2005), and Silverman and Kulinna (1999).

Mermier et al (1993) studied the relationship between HR and VE. They pointed out the difficulty of usable direct methods for measuring VE during PE. They used a regression curve of HR and VE to find out the values of breathed air volume. They found that HR can be used as an indirect method to setting VE. The type of breathing is also essential. When breathing through the nose, the amount of aerosol which is passed into lower air passages is lower than when a person breathes through the mouth. In this case, in polluted air it is healthier breathe through the nose.

Resting values are very difficult to find out especially in children. Many studies use methods which activate stress reactions in children, but they tend to measure unreal values. This problem was avoided in a study by Wallis et al (2005) who used a method of eliminating the rise of HR resting values during measurement in their study of 1109 healthy British children aged 4 to 16 . Their results were always 1 to 2 beats lower than studies which proceeded too fast. Wallis et al (2005) did not find a significant difference in HR between boys and girls.

VE is one of the most important factors for judging aerosol exposure (Zuurbier et al, 2009). Similarly, VE values change with age and it is difficult to measure them, especially in children. The respiratory rate of a healthy 1 year old child is about 22 cycles a minute. In 10 year olds it is about 18 , in 11 to 12 year olds - 17, in 13 year olds - 16 and in 14 year olds - 15 breaths a minute (Wallis et al, 2005). The resting VE value has a close relationship to body surface size and corresponding basal metabolism (BM) according to age and sex. Therefore, we have used this method in our observed group. 
Many studies prove the risk of harming health by aerosol (Pope et al, 2002; 2007; 2009). WHO (World Health Organisation) limits of aerosol for health protection do not differentiate air into indoor and outdoor enviromnments (WHO, 2006).

The extensive WHO document results from many epidemiological studies and determines limits $50 \mu \mathrm{g} \cdot \mathrm{m}^{-3} \mathrm{PM}_{10}$ and $25 \mu \mathrm{g} \cdot \mathrm{m}^{-3} \mathrm{PM}_{2.5}$ for public health protection in a 24-hour average (for the purpose of this study we call it WHO A limit). The yearly average limit is 20 $\mu \mathrm{g} \cdot \mathrm{m}^{-3} \mathrm{PM}_{10}$ and $10 \mu \mathrm{g} \cdot \mathrm{m}^{-3} \mathrm{PM}_{2.5}$. These values are reliable indicators (out of $95 \%$ ) of protection against possible damage of the cardiopulmonary system and lung tumour. When exceeding this limit, the risk of health damage rises. The treble value of WHO A limit, $\mathrm{PM}_{10}$ $150 \mu \mathrm{g} \cdot \mathrm{m}^{-3}$ and $\mathrm{PM}_{2.5} 75 \mu \mathrm{g} \cdot \mathrm{m}^{-3}$, leads to a $5 \%$ increase in short term mortality (judged based on the published risk coefficients in multicentre studies and meta-analyses (WHO, 2006) (for the purpose of this study we call this limit WHO B limit). The WHO document states that there is no evidence for the difference in the danger from outer and inner aerosol, and it is not necessary to set limits for both environments separately.

\section{Methods}

The observed schools were chosen with the aim to cover the most typical Prague school environments. Those were a school in the city centre (ZS1), in the river valley close to frequented city streets; a school in the urban periphery (ZS2), on a well ventilated plateau; and a school in the suburbs (ZS3), out of traffic, close to nature.

The PE lesson corresponded to the structure, content and load of common PE lessons at the observed schools.

Picture 1: The situation of the observed schools on the map

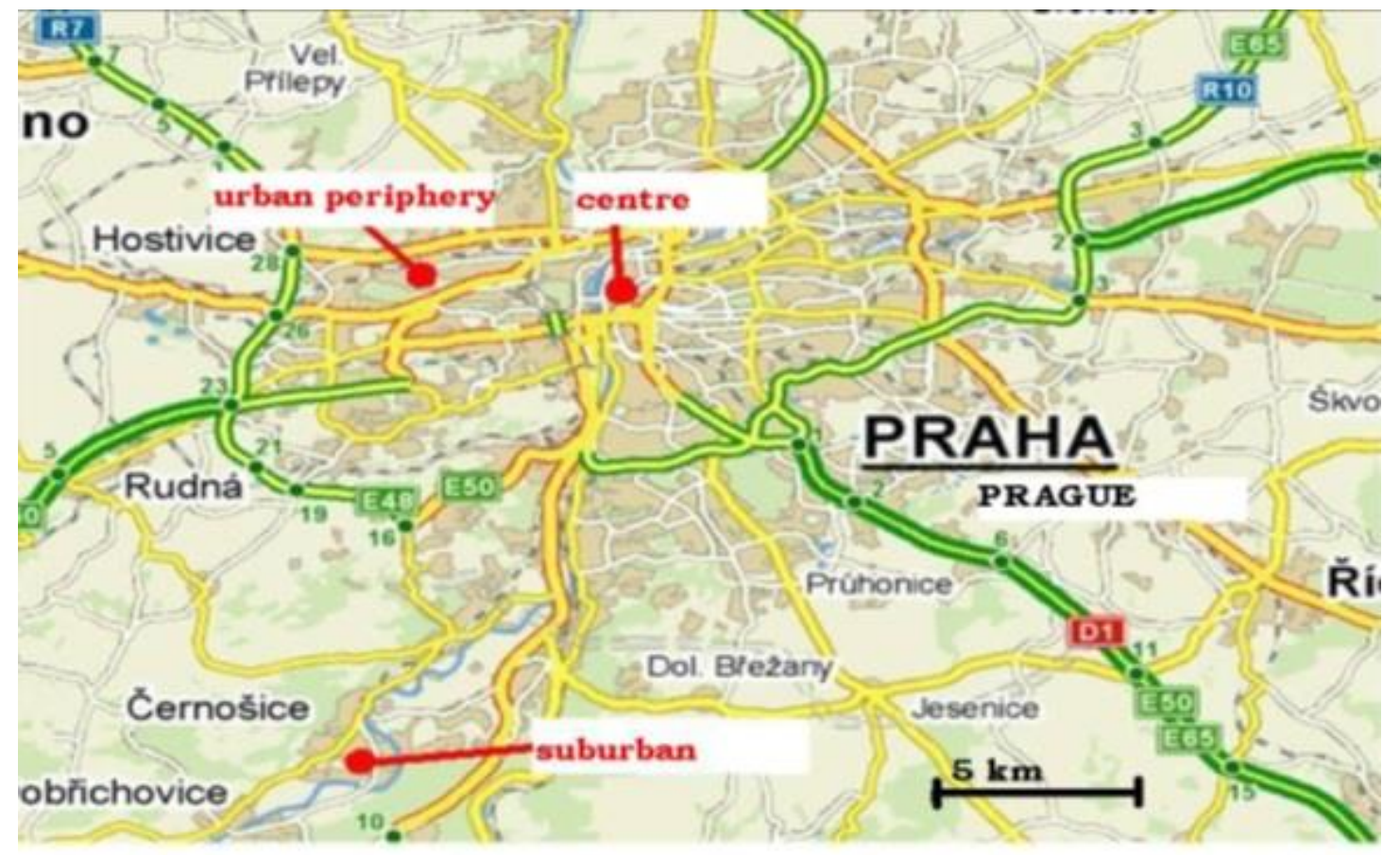

ZS1 - centre, ZS2 - urban periphery, ZS3 - suburban 
Aerosol concentration measurements were recorded from November 2005 till August 2009. 177 days of inner and outer measurements were made in 20 campaigns, 7 to 11 days long, covering most of the year. 10 campaigns in ZS1 and 5 campaigns in ZS2 and ZS3. In 112 days, school gyms were used for PE lessons - 63 days in ZS1, 20 days in ZS2 and 29 days in ZS3. To measure aerosol concentrations, we have used the low-volume $\left(9 \mathrm{l} \cdot \mathrm{min}^{-1}\right.$ ) PCIS (Personal Cascade Impactor Sampler) (Misra et al, 2002). Aerosol is trapped by filters in 5 grades $A$ to $F(A: 2.5-10 \mu \mathrm{m}, \mathrm{B}: 1.0-2.5 \mu \mathrm{m}, \mathrm{C}: 0.5-1.0 \mu \mathrm{m}, \mathrm{D}: 0.25-0.5 \mu \mathrm{m}$ and $\mathrm{F}$ : $<0.25 \mu \mathrm{m}$ ). Concentrations were set gravimetrically. Concentrations PM 2.5 were also continuously recorded by a photometer TSI Dust Trak (DT) in 5 minute intervals. Data from the photometer served to estimate the real hour aerosol concentrations during PE lessons, where we also measured the intensity of the children's physical load. Commeter D3121 observed temperature and relative humidity. Monitor sensors for temperature measurement and humidity were placed next to the instruments for measuring aerosol concentrations.

We used two identical instruments for the measurements in indoor and outdoor environments. Instruments were placed indoors into a wall nook sealed against outer air intrusion and protected by iron fencing towards the gym, so instruments could not be damaged by balls or unauthorised tampering. Monitor sensors were 2 to 3 metres above the gym floor. The outer instruments were placed on the school roof or on an unused school balcony.

All three school buildings are naturally ventilated by double windows and have central heating using natural gas. Gyms were in operation from 8 a.m. when regular PE lessons started. In the afternoon gyms were used for childrens' after-school sport activities and in the evening the gyms were rented by other organisations for sport activities.

The number of lessons and number of people at every lesson were recorded by school employees in a report. Rates and length of activities were reviewed by one of the study authors with teachers and instructors for every campaign. We counted the activities in the gym each day by person hour (multiples of pupils' number and time in hours spent in the gym when exercising).

To compare our data we used data from the station "Automatic emission monitoring of the Czech hydro meteorological institute (AIM), Mlynářka in Prague 5", which is used for setting the weight concentration $\mathrm{PM}_{2.5}$ by the method $\beta$-atenuace. To compare it with the instrument AIM and our photometer DT we used the equivalent PM 2.5 from PCIS, the sum of all level fractions smaller than $2.5 \mu \mathrm{m}$. The hour concentrations $\mathrm{PM}_{2.5}$ from the station AIM were analysed to get a 24-hour average corresponding to the measurement regime of our PCIS (from 8 a.m. till 8 a.m. the following morning).

\section{Observed groups of pupils}

We chose $5^{\text {th }}$ grade pupils as representants of the first stage of primary school and $7^{\text {th }}$ and $8^{\text {th }}$ grade pupils as representants of the second stage of primary school to find out VE during PE lessons in the two schools (ZS1 and ZS2) where we measured aerosol concentrations. The observed group consisted of 32 respondents, in which we had the complete data out of all measurements.

Laboratory study of the pupils was undertaken in the Sport motoric laboratory at Charles University, Faculty of Physical Education and Sport. At first, measurements of basic anthropometry and body mass index were calculated. We measured pupils' weight and height. Spiroergometric treatment included an 8 minute warm up load (4 minutes at $7 \mathrm{~km} \cdot \mathrm{h}^{-}$

${ }^{1}$ and another 4 minutes at $9 \mathrm{~km} \cdot \mathrm{h}^{-1}$ at zero declination of the treadmill). After a short break, 
a maximal test followed. Pupils started at $9 \mathrm{~km} \cdot \mathrm{h}^{-1}$ at five degree declination. Every minute the speed increased by $1 \mathrm{~km} \cdot \mathrm{h}^{-1}$ until observable fatigue. Pupils were breathing into the air analyser Teem 100 during the activity and every 20 minutes the automatic record of VE was calculated. HR was continuously registered and recorded by the sport-tester Polar Vantage NV.

The second part, measuring the HR by sport-testers during PE lessons, was undertaken on the same day at the same time in both schools during morning PE lessons. The observed PE lessons were very similar in character, but the extent of their individual parts differed. Most teachers structured the lesson devoting time to organizing issues (14\%) and warming up $(21 \%$.). Relay runs occupied $18 \%$, a small period of time was devoted to game skills $(7 \%) .40 \%$ was devoted to dodge ball and a throwing game, although one class played dodge ball only briefly. All values are average out of the four observed lessons. Both teams proceeded in the same way. At the same time aerosol concentrations of fractions $\mathrm{PM}_{2.5}$ and $\mathrm{PM}_{10}$ were measured.

A table and figure describing an active regression curve of the dependence of $\mathrm{HR}$ and VE was compiled in Microsoft Excel for each individual based on the database from laboratory treatments of individual pupils, HR measurements during PE lessons and estimated resting volumes of VE. HR records from PE lessons were analysed and HR values classified into load zones. Zones are determined in the intervals of $10 \%$ of maximal HR value of the observed person. According to HR values in each zone we counted the time the observed person exercised in the zone. We read the corresponding VE from the mean value of HR load zone from the exponential regression curve of the observed person and counted ventilation for each zone. The probable overall VE in the measured exercise unit was gained by the sum of values from all zones. This value was compared with the probable resting VE in the measured exercise unit in every person and we counted the probable multiple of VE during physical load.

Out of the immediate and long-term values of air quality measurements in the observed gyms we counted the probable PM exposure of an average pupil and compared it with the concentration limits for the health protection set by the WHO (2006).

\section{Results}

The average HR of the group during the measured exercise unit was 150.6 beats per minute. The average VE multiple during the measured exercising was counted in the whole group to the value 3.8 times ( $\max .=5.4 ; \mathrm{min} .=2.7$; standard deviation 0.7 ). Ventilation value multiples of individual persons in the measured exercise unit significantly correlate with their average HR values in the exercise unit $(r=0.78)$. See Table 1 . Our measured values are slightly under the values stated by WHO in their extended studies (Table 2 ).

PM 2.5 values measured directly in lessons, when we observed the physical load of pupils during PE lessons, are mostly slightly higher than 24 hour averages. This outcome corresponds to findings from our previous studies on the level of resuspension even in size fractions of soft aerosol (Braniš, Šafránek, \& Hytychová, 2009, 2011; Braniš, \& Šafránek, 2011). Comparison with AIM values proves the assumption that from the data gained in these stations (they are in similar conditions and distances in kilometres as the observed place), it is possible to judge real values of pollution of size fraction PM 2.5 both outdoors and in a gym with the inaccuracy in physical unit frame $\mu \mathrm{g} \cdot \mathrm{m}^{-3}$ (Table 3). The situation in the 
area of rough aerosol PM $(2.5-10)$ is different. The level of its resuspension is high in our measured gyms, and probably in most school gyms, and its concentration during exercising in gyms is more than twice compared to the time no one exercises there (Figure 1 and 2).

Table 1: Physiological responses during laboratory tests and PE lessons (PEL)

\begin{tabular}{|c|c|c|c|c|c|c|c|c|c|}
\hline \multirow[t]{2}{*}{$N=32$} & \multirow[b]{2}{*}{ age } & \multicolumn{3}{|c|}{ Laboratory tests } & \multirow{2}{*}{\begin{tabular}{|c|} 
PEL \\
HR \\
mean \\
PEL
\end{tabular}} & \multicolumn{4}{|c|}{ Calculated values } \\
\hline & & $\begin{array}{c}\text { VE } \\
\left(1 \cdot \mathrm{min} .^{-}\right. \\
1)\end{array}$ & $\begin{array}{c}\text { HR } \\
\max \end{array}$ & $\begin{array}{c}80 \% \\
\text { HR } \\
\max \end{array}$ & & $\begin{array}{c}\text { VE } \\
\left(I \cdot \text { min. }^{-1}\right) \\
\text { resting }\end{array}$ & $\begin{array}{c}\text { VE }(\mathrm{I}) \\
\text { resting/ } \\
\text { time PEL }\end{array}$ & $\begin{array}{c}\text { VE(I) } \\
\text { time } \\
\text { PEL }\end{array}$ & $\begin{array}{c}\text { multiple } \\
\text { resting } \\
\text { values } \\
\text { VE }\end{array}$ \\
\hline Mean & 12 & 66 & 207 & 165 & 151 & 6.5 & 260.3 & 990.2 & 3.8 \\
\hline Med. & 11.5 & 66.7 & 206.5 & 167 & 151 & 6.4 & 260.6 & 962.2 & 3.8 \\
\hline Max. & 14 & 90.3 & 221 & 175 & 170 & 7.7 & 340.5 & 1549 & 5.4 \\
\hline Min. & 10 & 45 & 196 & 157 & 129 & 5.2 & 203.6 & 622.9 & 2.7 \\
\hline SD & 1.3 & 11.2 & 6.1 & 4.6 & 10.9 & 0.73 & 32 & 233.7 & 0.72 \\
\hline CV & 10 & 17 & 3.0 & 2.8 & 7.2 & 11.2 & 12.3 & 23.6 & 1.9 \\
\hline
\end{tabular}

$\mathrm{N}=$ number, $\mathrm{VE}=$ pulmonary ventilation, $\mathrm{HR}=$ heart rate, $\mathrm{SD}=$ standard deviation, $\mathrm{CV}=$ coefficient of variation, $\mathrm{PEL}=$ physical education lessons

Table 2: Ventilation factors in children at different load VE - (I-min.-1) (EPA Exposure factors handbook, 2011)

\begin{tabular}{|c|c|c|c|c|c|c|c|}
\hline gั & 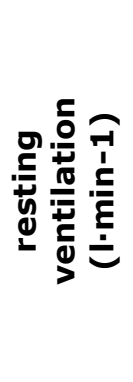 & 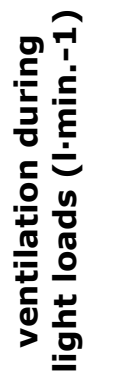 & 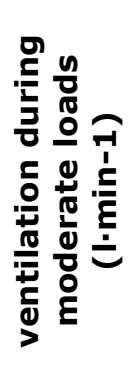 & 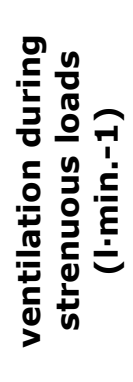 & 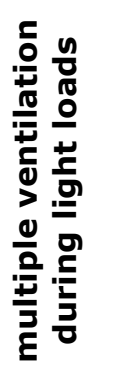 & 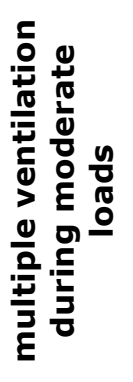 & 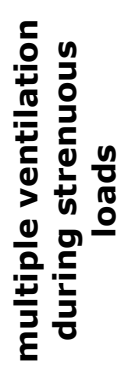 \\
\hline $6-11$ & 4.8 & 11 & 22 & 42 & 2.29 & 4.58 & 8.75 \\
\hline $11-16$ & 5.4 & 13 & 25 & 54 & 2.41 & 4.26 & 9.07 \\
\hline
\end{tabular}

$\mathrm{VE}=$ pulmonary ventilation 
Table 3: The average 24-hour concentration for all monitored days PM2.5 $(\mu \mathrm{g} \cdot \mathrm{m}-3)$

\begin{tabular}{|l|c|c|c|}
\hline School & $\begin{array}{c}\text { Outdoor environ- } \\
\text { ment }\end{array}$ & Indoor environment & AIM \\
\hline ZS1 & 30.1 & 24.0 & 25.5 \\
\hline ZS2 & 14.1 & 15.0 & 19.0 \\
\hline ZS3 & 21.2 & 23.5 & 19.7 \\
\hline
\end{tabular}

$\mathrm{PM}=$ particulate matter, $\mathrm{ZS} 1=\mathrm{school}$ in the centre, $\mathrm{ZS2}=\mathrm{school}$ in the urban periphery, ZS3=suburban school, AIM= automatic emission monitoring (Czech hydro meteorological institute)

Figure 1 and 2: The average 24-hour concentration PM and number of exercising pupils

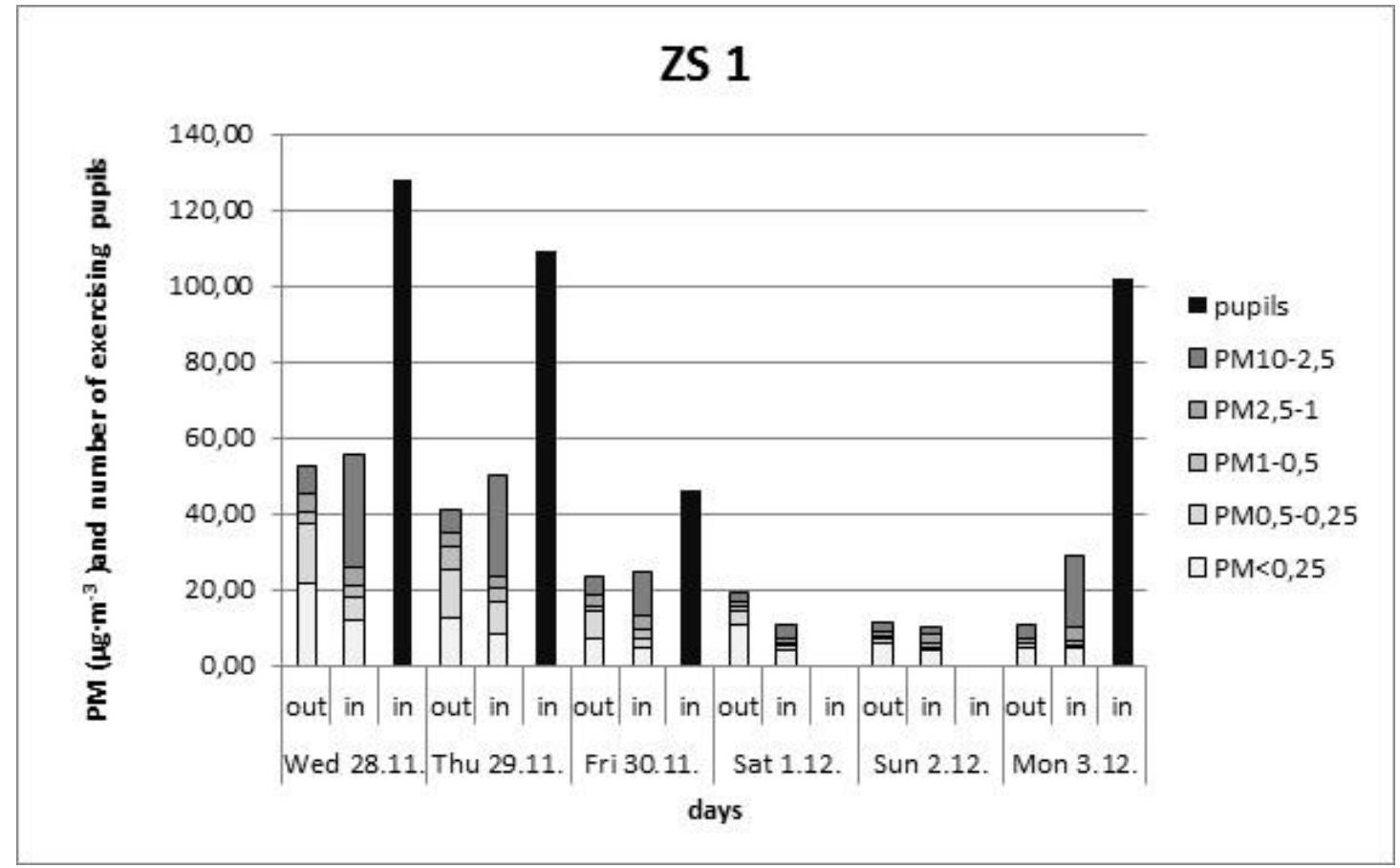

$\mathrm{ZS} 1=$ school in the city centre, PM=particulate matter 


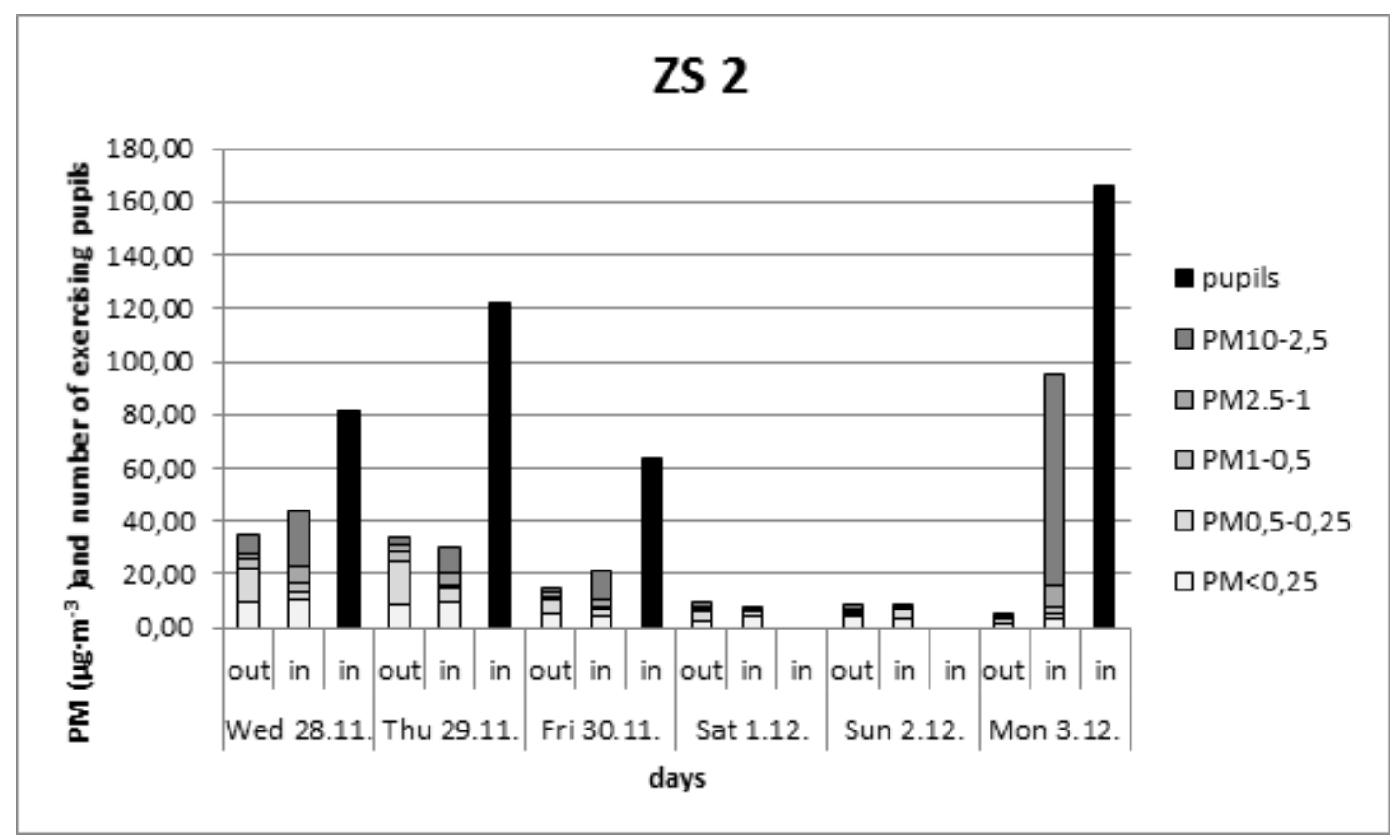

Legend: $\mathrm{ZS2}=$ school in the urban periphery, $\mathrm{PM}=$ particulate matter

To judge the influence of human activity on concentrations of rough aerosol in gyms we need data about gym use. Despite the aim to control records the extent of observation is so big we cannot fully avoid the influence of a human factor. However, the validity of data is proven by comparing the extent of human activity in gyms - person hours and aerosol concentrations between the days when pupils exercised and days when the gym was empty. Correlation between person hours and rough fraction of aerosol PM (2.5 - 10) measured in days when pupils exercised is (0.77). It proves a high dependence between these variables, even despite the impossibility to cover the influence of different PE lessons on the amount of resuspended aerosol both in a positive and negative way. These figures evaluate at the same time the pollution of outdoor air. When accepting conclusions of the WHO study (it is not necessary to distinguish outdoor and indoor aerosol as in terms of health risks, there is almost no difference between soft and rough aerosol fractions) we can evaluate on this scale conditions for exercising in a gym and on an outdoor playground at the same time. The outdoor air was less polluted in 7 out of 8 days in which pupils exercised. For all observed days in which pupils exercised, we compiled the probable exposure of exercised pupils to aerosol outdoors and indoors in relation to the WHO air quality limits for health protection (Figure 3 and Table 4).

Figure 3: WHO air quality limits for 24-hour average $P M_{2.5}=75, \mathrm{PM}_{10}=150\left(\mu \mathrm{g} \cdot \mathrm{m}^{-3}\right)$ 


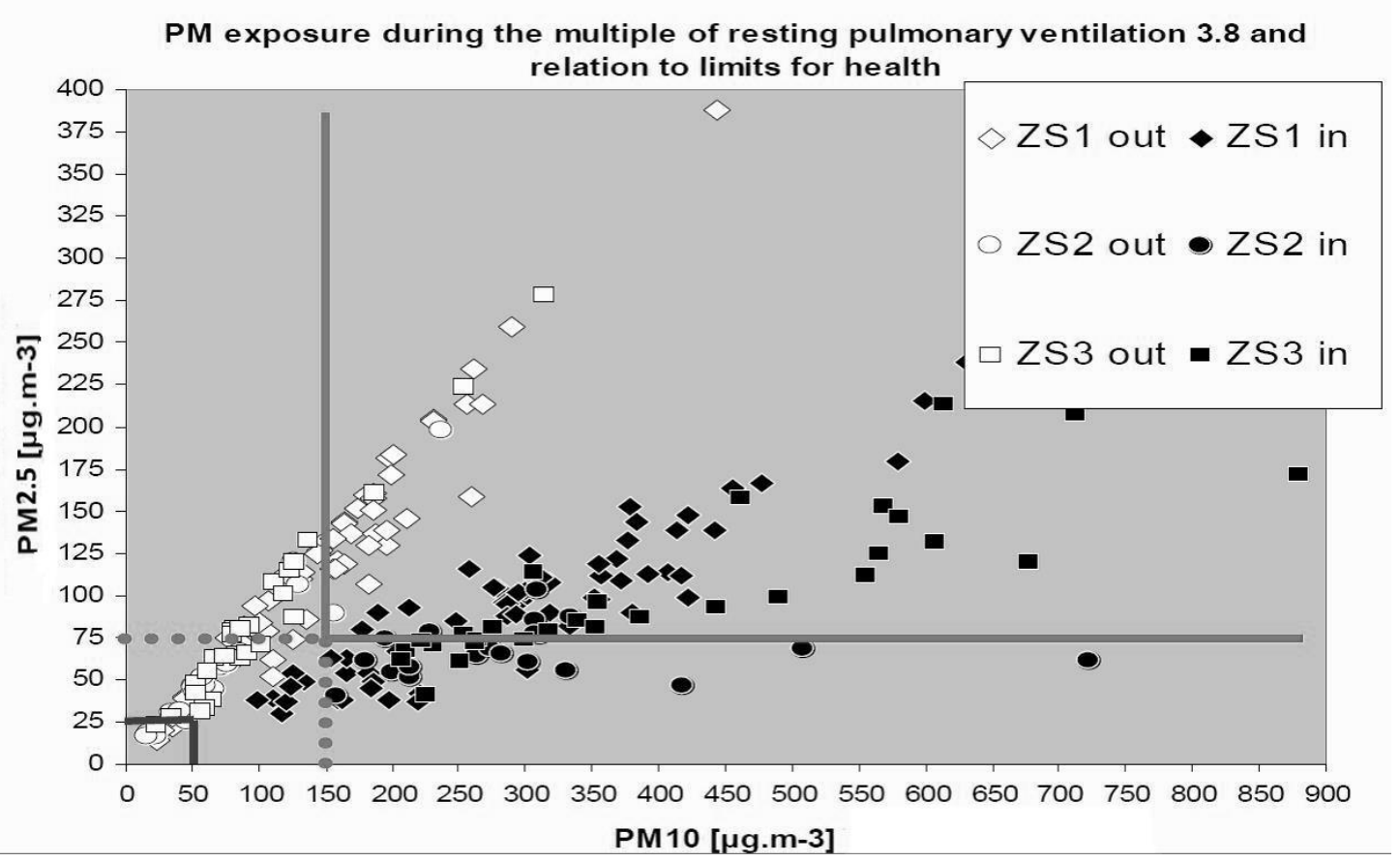

Legend: $\mathrm{PM}=$ particulate matter, $\mathrm{ZS} 1=$ school in the centre, $\mathrm{ZS} 2=$ school in the urban periphery, ZS3=suburban school. In the green framework, both values PM are under the limit (limit WHO A). In the red pointed framework both values are under the limit (limit WHO B). In the red square full line both values are above limits.

In all monitored schools the air quality limits set by WHO were exceeded in $89 \%$ of days in gyms and in $46 \%$ of days in the outdoor environment (on the playground).

Overall, better conditions for exercising are found outdoors. The best conditions for exercising were ZS2 in the urban periphery - only $10 \%$ of days outdoors and $30 \%$ of days indoors, when comparing to WHO limits, were fully unsuitable for exercising. The worst conditions were ZS1 in the city centre - $48 \%$ of days outdoors and $67 \%$ of days in the gym were fully unsuitable for exercising. ZS3 in the suburbs had like ZS2 only $10 \%$ of days outdoors fully unsuitable for exercising, however, $69 \%$ of days fully unsuitable for exercising in a gym. The probable PM exposure of exercising pupils was in ZS3 significantly in detriment of the inner environment.

During this evaluation it is not possible to cover the level of possible exposure in relation to values of individual size fractions, in individual environments in individual schools in days pupils exercised. According to our measurements the outdoor environment was best in size fractions $\mathrm{PM}_{10}$ in ZS2 in the urban periphery and worst in ZS1 in the city centre. Overall, the outdoor air in the fraction $\mathrm{PM}_{10}$ was the only one under the acceptable exposition border (comparing to WHO limits). The outdoor environment in the size fraction $\mathrm{PM}_{2.5}$ was best in ZS2, as the only one under the acceptable exposition border.

The worst was the outdoor environment of ZS1. The worst conditions among gyms in the fraction $\mathrm{PM}_{10}$ were significant in ZS3. The gyms in ZS1 and ZS2 were in this scale similar, both significantly above the acceptable exposition border. When evaluating conditions for physical education in the observed schools, exercising outdoors is less risky from the point 
of view of possible negative influence of aerosol on pupils' health than exercising indoors. This statement is truest for schools 2 and 3, which had a significant difference between air cleanliness outdoors and in their gym. The school in the city centre did not have such a big difference between the outdoor and indoor environment mainly in the parameter $\mathrm{PM}_{10}$. Out of all three schools, it had the cleanest gym, despite the fact it lies in the city centre and close to roads with heavy traffic. The outdoor environment was more suitable for exercising than the inner from the point of view of air pollution by aerosol.

Table 4: Probable exposure of pupils during the 3.8 VE multiple and the double value of $\mathrm{PM}_{10}$ concentration in gyms, in relation to WHO limits $=\left(24\right.$ hour average concentrations $-\mathrm{PM}_{10}$ - $150 \mu \mathrm{g} \cdot \mathrm{m}^{-3} ; \mathrm{PM}_{2.5}-75 \mu \mathrm{g} \cdot \mathrm{m}^{-3}$ ) for indoor and outdoor environment

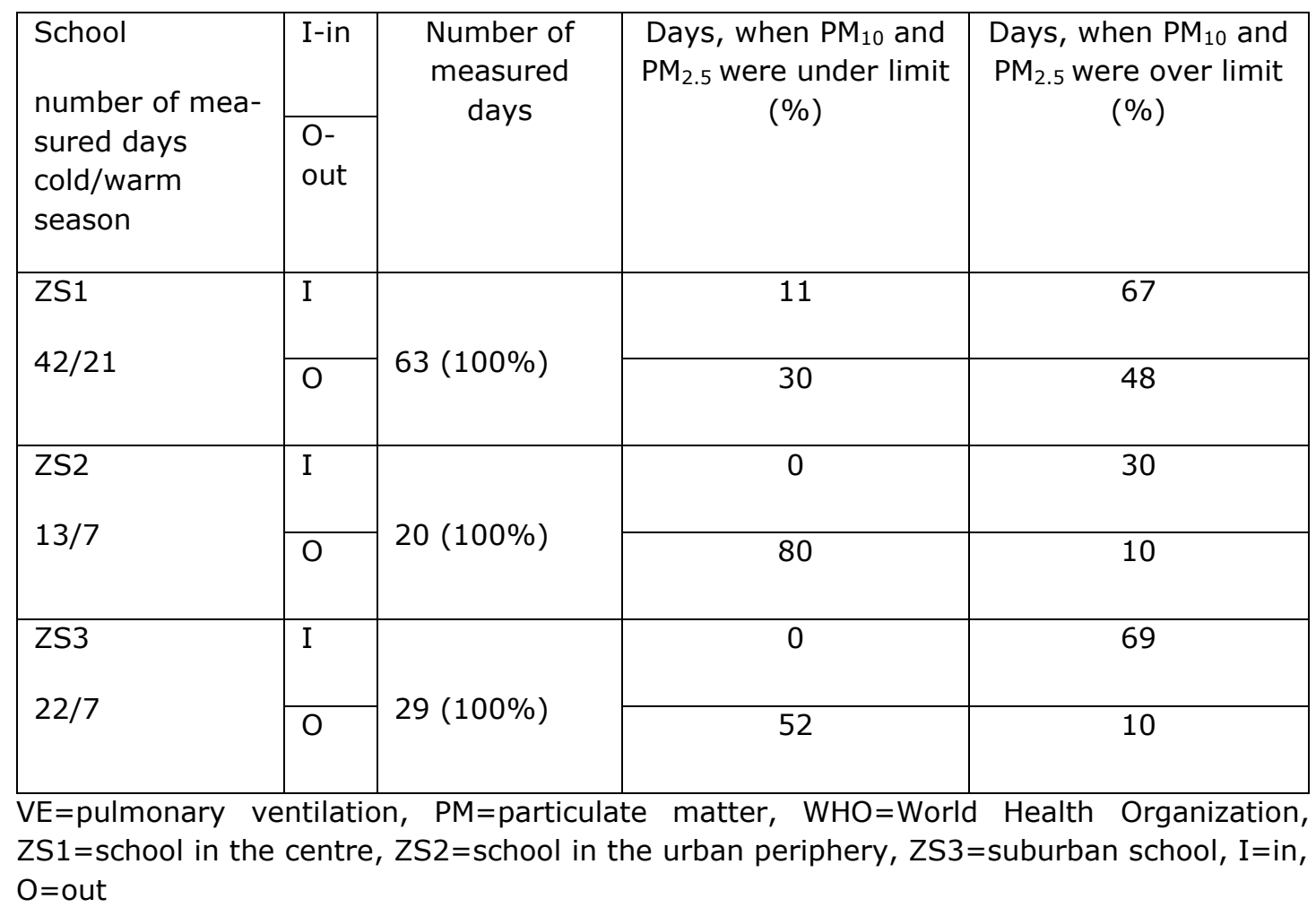

\section{Discussion and conclusions}

There have been more and more studies recently which deal with the quality of air in schools (Mejía et al, 2011; Habil, \& Taneja, 2011; Diapouli, Chaloulakou, \& Spyrellis, 2007; Ekmekcioglu, \& Keskin, 2007; Lee, \& Chang, 2000). However, there are no studies dealing with school gyms in detail. Those that have been conducted study gym use from the perspective of the number of pupils and PE lessons or they do not describe methods of gathering data. Common to all results of these studies is that they often exceed limits for health protection. Some results of the above referred authors are not gained by referential methods, but phono metrically. Phono metres usually overrate the measured concentrations, so the collected data are not very reliable, but nevertheless, they prove high exposures of aerosol in schools mainly in the winter season. Fromme et al (2007) showed that physical activity, which is higher in younger children, implicates higher resuspension and therefore higher 
aerosol concentrations in classes in lower primary schools. This phenomenon rises dynamically when there is a large number of children moving in a certain micro environment in a specific way (such as a gym). According to our assessment, the actual concentrations of aerosol during exercising are at least twice as high in comparison to the measured 24 hour concentrations (Figure 1 and 2). Our selected conservative double figure for counting the exposition to the rough aerosol is probably on the bottom level of the rate between the real immediate concentration value of rough aerosol and its 24-hour average. Exposure values set on the basis of WHO limits for health protection are in gyms significantly exceeded mainly in the fraction $\mathrm{PM}_{10}$. Expositions to soft aerosol $\left(\mathrm{PM}_{2.5}\right)$ are exceeded to a lesser degree. Nevertheless, some authors proved that high concentrations of rough and soft aerosol particles can be risky, however, in a different way. The level of risk of rough and soft aerosol particles has been long discussed and explored (Iskandar et al, 2012; Vaclavik-Bräuner et al, 2007; DeKok et al, 2006; Brunekreef, \& Forsberg, 2005; Fox et al, 2005; Atkinson, 1997).

When discussing conditions for physical education in the observed schools, in the heating season not only are dust limits exceeded in gyms, but also the bottom border of the hygiene limit for relative humidity for schools (30\%). Therefore, we can suppose that excessively dry air can cause many unpleasant feelings during physical activity evocated by drying of mucous in the mouth and nose, or it can lead to partial body dehydration. Combined with higher dust concentrations, the physical comfort of exercising pupils will probably decline.

We recommend the indoor areas in which pupils exercise should be cleaned with more care than places in which pupils stay are sedantry. Teachers and other responsible school staff should judge the situation not only according to the school gym cleanliness, but also in context with other micro-climatic factors, level of air pollution outdoors and meteorological conditions. In relation to these conditions they should reconsider the location of PE lessons and the intensity of the physical load.

Although the data were collected some time ago, the dustiness of the inner environment is mainly dependant on the gym regime and its cleaning, which does not change in principle, as well as the load of exercising pupils during PE lessons (those who exercise). One of the gyms significantly changed its cleaning regime during our measurements, although this was not influenced by the authors.

\section{References}

- Atkinson, G. (1997). Air pollution and exercise. Sports Exercise and Injury, 3(1), 2-8.

- Braniš, M., Šafránek, J., \& Hytychová, A. (2009). Exposure of children to airborne particulate matter of different size fractions during indoor physical education at school. Building and Environment, 44(6), 1246-1252. Retrieved from http://linkinghub.elsevier.com/retrieve/pii/S0360132308002308 http://dx.doi.org/10.1016/j.buildenv.2008.09.010

- Braniš, M., Šafránek, J., \& Hytychová, A. (2011). Indoor and outdoor sources of size-resolved mass concentration of particulate matter in a school gym - implications for exposure of exercising children. Environmental Science and Pollution Research, 18(4), 598-609. Retrieved from http://link.springer.com/10.1007/s11356010-0405-0 http://dx.doi.org/10.1007/s11356-010-0405-0 
- Braniš, M., \& Šafránek, J. (2011). Characterization of coarse particulate matter in school gyms. Environmental Research, 111(4), 485-491. Retrieved from http://linkinghub.elsevier.com/retrieve/pii/S0013935111000934

http://dx.doi.org/10.1016/j.envres.2011.03.010

- Brunekreef, B., \& Forsberg, B. (2005). Epidemiological evidence of effects of coarse airborne particles on health. Eur. Respir. J, 26(2), 309-318. Retrieved from http://erj.ersjournals.com/cgi/doi/10.1183/09031936.05.00001805 http://dx.doi.org/10.1183/09031936.05.00001805

- Carlisle, A., \& Sharp, N. (2001). Exercise and outdoor ambient air pollution. British Journal of Sports Medicine, 35(4), 214-222. Retrieved from http://bjsm.bmj.com/cgi/doi/10.1136/bjsm.35.4.214 http://dx.doi.org/10.1136/bjsm.35.4.214

- Daigle, C. C., Chalupa, D. C., Gibb, F. R., Morrow, P. E., Oberdorster, G., Uttel, M. J., \& Frampton, M. W. (2003). Ultrafine particle deposition in humans during rest and exercise. Inhalation Toxicology, 15(6), 539-552. Retrieved from http://www.tandfonline.com/doi/full/10.1080/08958370304468 http://dx.doi.org/10.1080/08958370304468

- DeKok, T. M. C. M., Driece, H. A. L., Hogervorst, J. G. F., \& Briede, J. J. (2006). Toxicological assessment of ambient and traffic-related particulate matter: A review of recent studies. Mutat Res, 613(2-3), 103-122. Retrieved from http://linkinghub.elsevier.com/retrieve/pii/S1383574206000433 http://dx.doi.org/10.1016/j.mrrev.2006.07.001

- Diapouli, E., Chaloulakou, A., \& Spyrellis, N. (2007). Indoor and outdoor particulate matter concentrations at schools in the Athens area. Indoor and Built Environment, 16(1), 55-61. Retrieved from http://journals.sage-

pub.com/doi/10.1177/1420326X06074836 http://dx.doi.org/10.1177/1420326X06074836

- Ekmekcioglu, D., \& Keskin, S. S. (2007). Characterization of indoor air particulate matter in selected elementary schools in Istanbul Turkey. Indoor and Built Environment, 16(2), 169-176. Retrieved from http://journals.sagepub.com/doi/10.1177/1420326X07076777 http://dx.doi.org/10.1177/1420326X07076777

- Fairclough, S., \& Stratton, G. (2005). Physical education makes you fit and healthy'. Physical education's contribution to young people's physical activity levels. Health Educational Research, 20(1), 14-23. Retrieved from https://academic.oup.com/her/article-lookup/doi/10.1093/her/cyg101 http://dx.doi.org/10.1093/her/cyg101

- Fox, A., Harley, W., Feigley, C., Salzberg, D., Toole, C., Sebastian, A., \& Larsson, L. (2005). Large particles are responsible for elevated bacterial marker levels in school air upon occupation. J. Environ. Monit, 7(5), 450-456. Retrieved from http://xlink.rsc.org/?DOI=b418038k http://dx.doi.org/10.1039/b418038k

- Fromme, H., Twardella, D., Dietrich, S., Heitmann, D., Schierl, R., Liebl, B., \& Rüden, H. (2007). Particulate matter in the indoor air of classrooms - exploratory results from Munich and surrounding area. Atmospheric Environment, 41(4), 854- 
866. Retrieved from http://linkinghub.elsevier.com/retrieve/pii/S1352231006009046 http://dx.doi.org/10.1016/j.atmosenv.2006.08.053

- Habil, M., \& Taneja, A. (2011). Children's exposure to indoor particulate matter in naturally ventilated schools in India. Indoor and Built Environment, 20(4), 430448. Retrieved from http://journals. sagepub.com/doi/10.1177/1420326X11409455 http://dx.doi.org/10.1177/1420326X11409455

- Iskandar, A., Andersen, J., Bønnelykke, Z., Ellermann, K., T Kaae Andersen,, , K, , \& Bisgaard, H. (2012). Coarse and fine particles but not ultrafine particles in urban air trigger hospital admission for asthma in children. Thorax, 67(3), 252-257. Retrieved from http://thorax.bmj.com/lookup/doi/10.1136/thoraxjnl-2011-200324 http://dx.doi.org/10.1136/thoraxjnl-2011-200324

- Kotlík, B., Kazmanová, H., Kratěnová, J., \& Holcátová, I. (2001). Monitoring the indoor environment in the Czech Republic. Indoor and Built Environment, 10(3), 154-159. Retrieved from http://journals.sagepub.com/doi/10.1177/1420326X0101000306 http://dx.doi.org/10.1177/1420326X0101000306

- Lee, S. C., \& Chang, M. (2000). Indoor and outdoor air quality investigation at schools in. Hong Kong, Chemosphere, 41, 109-113.

- Mejía, J. F., Choy, S. L., Mengersen, K., \& Morawska, L. (2011). Methodology for assessing exposure and impacts of air pollutants in school children: Data collection, analysis and health effects - A literature review. Atmospheric Environment, 45(4), 813-823. Retrieved from http://linkinghub.elsevier.com/retrieve/pii/S1352231010009647 http://dx.doi.org/10.1016/j.atmosenv.2010.11.009

- Mermier, C. M., Samet, J. M., Lambert, W. E., \& Chick, T. W. (1993). Assessment of heart rate as a predictor of ventilation. Research Report Health Effect Institute, 59, 19-55.

- Misra, C., Singh, M., Shen, S., Sioutas, C., \& Hall, P. M. (2002). Development and evaluation of a personal cascade impactor sampler (PCIS. Journal of Aerosol Science, 33(7), 1027-1047. Retrieved from http://linkinghub.elsevier.com/retrieve/pii/S0021850202000551 http://dx.doi.org/10.1016/S00218502(02)00055-1

- Pope, C. A. III., Burnett, R, T, Thun, M. J., Calle, E. E., Krewski, D., Ito, K., \& Thurston, G. D. (2002). Lung cancer, cardiopulmonary mortality, and long-term exposure to fine particulate air pollution. JAMA, 287(9), 1132-1141. Retrieved from http://jama.jamanetwork.com/article.aspx?doi=10.1001/jama.287.9.1132 http://dx.doi.org/10.1001/jama.287.9.1132

- Pope, C. A. III., Rodermund, D L, , \& Gee, M. M. (2007). Mortality effects of a copper smelter strike and reduced ambient sulphate particulate matter air pollution. Environmental Health Perspectives, 115(5), 679-683. Retrieved from http://www.ncbi.nlm.nih.gov/pmc/articles/PMC1867960 http://dx.doi.org/10.1289/ehp.9762 
- Pope, C. A. III., Ezzati, M, , \& Dockery, D. W. (2009). Fine-particulate air pollution and life expectancy in the United States. New England Journal Medicine, 360(4), 376-386. Retrieved from http://www.nejm.org/doi/abs/10.1056/NEJMsa0805646 http://dx.doi.org/10.1056/NEJMsa0805646

- Silverman, S., \& Kulinna, P. H. (1999). What Are Children's Heart-Rates during British Physical Education Lessons? The. Journal of Physical Education, Recreation \& Dance, 70(2), 8-8. Retrieved from http://www.tandfonline.com/doi/abs/10.1080/07303084.1999.10605658 http://dx.doi.org/10.1080/07303084.1999.10605658

- Stratton, G. (1996). Children's heart rates during British physical education lessons. Journal of Teaching in Physical Education Paediatric Exercise Science, 8(3), 215-233. Retrieved from http://journals. humankinetics.com/doi/10.1123/pes.8.3.215 http://dx.doi.org/10.1123/pes.8.3.215

- Vaclavik-Bräuner, E., Forchhammer, L., Møller, P., Simonsen, J., Glasius, M., \& Wahlin, P. (2007). Exposure to ultrafine particles from ambient air and oxidative stress-induced cDNA damage. Environ Health Perspect, 115(8), 1171-82.

- Wallis, L. A., Healy, M., Undy, M. B., \& Maconochie, I. (2005). Age related reference ranges for respiration rate and heart rate from 4 to 16 years. Archives of Disease in Childhood, 90(11), 1117-1121. Retrieved from http://adc.bmj.com/cgi/doi/10.1136/adc.2004.068718 http://dx.doi.org/10.1136/adc.2004.068718

- Wang, G. Y., Pereira, B., \& Mota, J. (2005). Indoor physical education measured by heart rate monitor. A case study in Portugal. Journal of Sports Medicine and Physical Fitness, 45(2), 171-177.

- WHO, (2006). World Health Organization. Air quality guidelines for particulate matter, ozone, nitrogen dioxide and sulphur dioxide. Global update 2005. Summary of risk assessment [online]. c2006, [2012-02-28]. . Retrieved from http://whqlibdoc.who.int/hq/2006/WHO SDE PHE OEH 06.02 eng.pdf

- Zuurbier, M., Hoek, G., Hazell, P., \& Brunekreef, B. (2009). Minute ventilation of cyclists, car and bus passengers: an experimental study. Environmental Health, 8(1), Retrieved from http://ehjournal.biomedcentral.com/articles/10.1186/1476-069X-8-48 http://dx.doi.org/10.1186/1476-069X-8-48 


\begin{abstract}
Jiří Šafránek, Ivana Turčová, Michal Hájek
Univerzita Karlova v Praze, Fakulta tělesné výchovy a sporu, Katedra sportů v prírodě, José Martího 31, 16252 Praha 6

Prof. RNDr. Martin Braniš, CSc. (6. ledna 1952, Praha - 27. září 2013, Praha)

Významná osobnost českého akademického světa. Absolvent Přrirodovědecké fakulty Univerzity Karlovy v Praze. Od roku 1991 působil v Ústavu pro životní prostredí na téže fakultě, který spoluzakládal, a kde také téměř až do svého předčasného úmrtí, stř́ldavě v roli ředitele a zástupce ředitele, pracoval. Byl autorem řady vědeckých a odborných publikací $v$ oblasti ekologie a ochrany životniho prostředi. V poslednich letech svého života svůj vědecký zájem, který měl velký presah do řady společenských a přirodnich věd, směroval ke kvalitě ovzduší. Za mimořádný př́nos pro životni prostředi byl v roce 2008 oceněn ministrem životního prostředi $\check{C} R$.
\end{abstract}

